\title{
Long-term decline in egg size of Atlantic puffins Fratercula arctica is related to changes in forage fish stocks and climate conditions
}

\author{
Robert T. Barrett ${ }^{1, *}$, Erlend B. Nilsen ${ }^{2}$, Tycho Anker-Nilssen ${ }^{2}$ \\ ${ }^{1}$ Department of Natural Sciences, Tromsø University Museum, 9037 Tromsø, Norway \\ ${ }^{2}$ Norwegian Institute for Nature Research (NINA), PO Box 5685 Sluppen, 7485 Trondheim, Norway
}

ABSTRACT: Due to major shifts in the marine ecosystem, many seabirds in the NE Atlantic have experienced short- and long-term breeding failures and population changes. One such seabird is the Atlantic puffin Fratercula arctica, the populations of which have declined in Norway at an annual rate of $2 \%$ over a $\sim 30 \mathrm{yr}$ period. Parallel to this decline, we found a significant decline in egg volume at 2 widely separated Norwegian colonies situated in different marine ecoregions, a decline that is unprecedented among auks. In birds, egg production is costly for the female and varies in response to the amount of energy available for reproduction. Whereas proximate factors determining egg size are largely unknown, food availability prior to egg-laying is considered important. Using generalised least-square models, we demonstrate that the declines in egg size were driven by interannual changes in abundances of capelin Mallotus villosus and early life stages of herring Clupea harengus and haddock Melanogrammus aeglefinus, all of which are important prey of Atlantic puffins in these colonies. Furthermore, changes in climatic variables, such as sea temperature and the North Atlantic Oscillation, suggest that other prey may also have played a role in determining puffin egg size. The decline in egg size may reduce the quality of future breeders and hence have negative effects on puffin populations.

KEY WORDS: Atlantic puffin - Egg size - Fish stocks $\cdot$ Climate

Resale or republication not permitted without written consent of the publisher

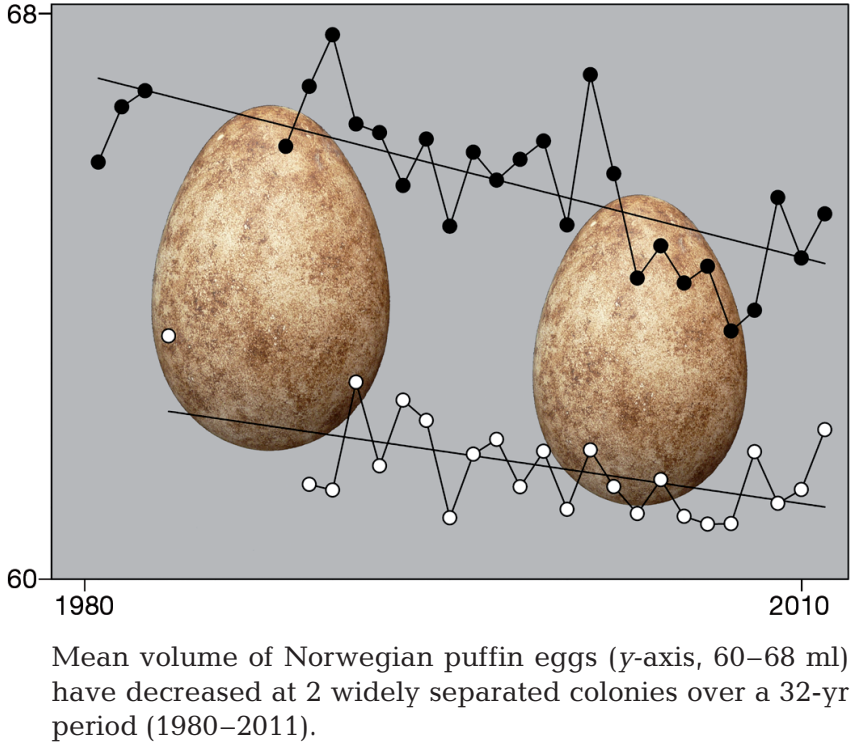

Image: Tycho Anker-Nilssen

\section{INTRODUCTION}

Optimal parental fitness is compromised by investment in reproduction and entails a trade-off for the parent between the production of a maximum number of independent offspring in any one season and its own self-maintenance and chances of future survival (e.g. Stearns 1992). Besides adjustments in brooding and feeding effort in response to environmental conditions, offspring production in birds can be regulated through changes in clutch size or, for species that lay only a single egg, egg size. 
Egg production is costly for the female and, although there is marked individual variation in reproductive traits, egg size within a species varies in response to the amount of energy invested in the eggs (Christians 2002, Williams 2005, Nager 2006). Among many species that are 'income breeders' (sensu Drent \& Daan 1980), environmental conditions, most importantly food availability immediately prior to or during egg-laying, are key determinants of egg size.

Whereas proximate factors determining egg size are largely unknown, food availability prior to or during the egg-formation period is considered an important determinant (e.g. Nager 2006, Jacobs et al. 2009, but see Christians 2002, Williams 2005, Sorensen et al. 2009). Other potential determinants are the physiological status of the female (e.g. endogenous protein stores, effects of reproduction hormones, production of yolk precursors and their uptake in the ovary) but these are, as yet, little explored (Christians 2002, Williams 2005).

Recent studies have addressed the possible effects of climate change on egg size, but results are equivocal (Potti 2008). This may be partly explained by some populations being unable to adjust for changes in the phenology of the nesting environment and the subsequent mismatch between timing of breeding and food availability (Potti 2008).

On a global scale, the marine food webs in the NE Atlantic are among those most strongly subjected to massive anthropogenic perturbations (most importantly, fishing, pollution and, recently, climate change) over the last 150 yr (Halpern et al. 2008). For example, major fish stocks in the North, Norwegian and Barents Seas, such as those of Norwegian spring-spawning (NSS) herring Clupea harengus, capelin Mallotus villosus, sandeels Ammodytes spp. and cod Gadus morhua have periodically collapsed, with severe consequences for the whole ecosystem (Skjoldal 2004, Gjøsæter et al. 2009a, Fauchald et al. 2011). Many seabirds feed at high trophic levels, and those breeding in the NE Atlantic have experienced major shifts in the ecosystem, resulting in short- and long-term breeding failures and population changes throughout the region (Ratcliffe 2004, Barrett et al. 2006). Because of their visibility, colonial breeding and ease of study, seabirds are good indicators of changes in marine ecosystems (Piatt et al. 2007). As such, fishing pressure in Norwegian waters, combined with recent climate-driven changes in primary, secondary and fish production, has been reflected in changes in breeding and behavioural parameters among seabirds breeding in the region (Cury et al. 2011).

The Atlantic puffin Fratercula arctica is the most numerous seabird breeding in mainland Norway (ca. 1.7 million pairs), with colonies spread along the coast from Rogaland in the south to the Varangerfjord in the northeast (Barrett et al. 2006, Anker-Nilssen 2011). Annual monitoring since 1979 has, however, documented a significant population decrease (on average $2.0 \% \mathrm{yr}^{-1}$ ) in colonies on the Norwegian Sea coast (Barrett et al. 2006), with the steepest drop $\left(3.3 \% \mathrm{yr}^{-1}\right)$ observed in the largest colony, Røst, which still holds about a quarter of the Norwegian population (Anker-Nilssen 2010). As a result, the species is categorised as vulnerable on the Norwegian Red List (Kålås et al. 2010).

Whereas effects of environmental factors on demographic parameters and diet composition are well documented (reviewed in Harris \& Wanless 2011), few studies of Atlantic puffins have investigated what pressures act during the pre- and early breeding season. The egg of the Atlantic puffin represents 14 to $16 \%$ of the female body mass and is among the largest relative to body mass among seabirds (Harris $\&$ Wanless 2011). As with any other income breeders, the female thus needs to allocate substantial resources to egg production, and will depend on sufficient intake of food resources to cover her energy and nutritional requirements during egg production (Nager 2006, Blight 2011). Because the conservation status of the Atlantic puffin is of concern and because there is a positive link between egg size and chick growth and survival (and potentially also future fecundity) (Krist 2011), it is also important to address the factors affecting the birds during their preparation for breeding. In the context of climate-forced changes in the marine environment and resulting effects on the prey base (e.g. Burrows et al. 2011), we analyse here long-term data sets (compiled largely by R. T. Barrett and T. Anker-Nilssen) relating to egg size of the Atlantic puffin breeding at 2 well separated North Norwegian colonies.

In the present study, we aim to document and explore the underlying causes of a long-term decline in egg volume of Atlantic puffins at the study colonies through the assessment of various factors known to affect clutch and egg size, such as adult body size, population age structure, breeding phenology and external environmental parameters including winter North Atlantic Oscillation (wNAO), sea-surface temperatures (SST), air temperatures and prey availability. 


\section{MATERIALS AND METHODS}

\section{Study colonies}

The breeding performance of Atlantic puffins was studied at 2 Norwegian colonies of contrasting size and population history: (1) the relatively small colony (ca. 10000 pairs in 2011) on Hornøya $\left(70^{\circ} 22^{\prime} \mathrm{N}\right.$, $31^{\circ} 08^{\prime} \mathrm{E}$ ) off Vardø at the eastern tip of the Varanger Peninsula, where breeding numbers have increased by an average of $2.3 \% \mathrm{yr}^{-1}$ and doubled between 1980 and 2009 (R. T. Barrett unpubl. data); and (2) the much larger colony on Hernyken ( $\left.67^{\circ} 26^{\prime} \mathrm{N}, 11^{\circ} 52^{\prime} \mathrm{E}\right)$ that makes up part of the Røst population (392000 pairs in 2011) in the Lofoten Islands, where a mean decline of $3.3 \% \mathrm{yr}^{-1}$ since 1979 reduced the population by $72 \%$ over the same $30 \mathrm{yr}$ period (AnkerNilssen 2010).

\section{Field protocols}

During annual inspections of permanently numbered nest burrows used to monitor Atlantic Puffin breeding demography and phenology at the 2 colonies from 1980 to 2011, the maximum lengths $(L)$ and breadths $(B)$ of all unattended eggs were measured (in most years) once to the nearest $0.1 \mathrm{~mm}$ using sliding callipers. Egg volume $(V)$ was determined using the equation $V=K \times L \times B^{2}$ (Hoyt 1979), where the constant $K=0.507$ (as suggested for egg shapes typical of Charadriiformes species). Eggs were measured in 27 different years on Hornøya and 25 on Hernyken (see Table S1 in the supplement at www. int-res.com/articles/suppl/m457p001_supp.pdf).

At Hornøya, chicks in the same burrows were weighed and measured 2 or 3 times at ca. $10 \mathrm{~d}$ intervals, and chick hatching dates were estimated using models relating wing length to age (see Barrett 2001 for details). At Hernyken, the study burrows were inspected at 2 to $6 \mathrm{~d}$ intervals throughout the hatching period; chick hatching dates were determined from these data with an accuracy of $\pm 1-3 \mathrm{~d}$. Laying date was estimated as hatching date minus incubation period (42 d; Myrberget 1962).

At Hornøya, adult Atlantic puffins were caught using fleyg nets, noose poles or noose mats placed in the entrances of breeding burrows, and the length of their wing (maximum flattened chord) and head + bill were measured to the nearest $1.0 \mathrm{~mm}$ using a stopped wing rule and a slide calliper, respectively. Body measurements were made by different experienced fieldworkers in 1980-1983 (R. T. Barrett), 1994
(K. E. Erikstad), 2003 (K. Eilertsen), 2004-2006 (K. Sagerup and K. E. Erikstad) and 2009 (R. T. Barrett).

At Hernyken, adult Atlantic puffins were most often captured in mist nets erected in the colony, occasionally in a large $\left(700 \mathrm{~m}^{2}\right)$ small-meshed fish net mounted across a small, steep-sided valley on the island. As on Hornøya, birds were measured by experienced persons in 1980-1986 (T. Anker-Nilssen, O. W. Røstad, P. Anker-Nilssen and G. Lid), 19881995 (T. Anker-Nilssen, H. S. Øyan and P. AnkerNilssen) and 1996-2009 (T. Aarvak and T. AnkerNilssen). Measurements included wing length (maximum flattened chord) to the nearest $1.0 \mathrm{~mm}$, bill length (culmen), head + bill length and bill depth (at gonys) to the nearest $0.1 \mathrm{~mm}$ using a slide calliper, and body mass to the nearest 5 or $1 \mathrm{~g}$ using a spring balance, but not all measurements were collected in all years. All captures at Hornøya and Hernyken were approved through individual ringing licenses issued to the field personnel by the Oslo and Stavanger Museum Ringing Centres.

\section{Environmental covariates and data selection}

Mean monthly SST were obtained from http://iridl. ldeo.columbia.edu/SOURCES/.NOAA/.NCDC/.ERSST /.version3b/.sst/. Considering coastal topography and the foraging routes of puffins, we chose single grid cells (spanning $1^{\circ}$ lat. $\times 1^{\circ}$ long.) west of Hernyken and northeast of Hornøya, respectively. Mean monthly air temperatures were obtained from the Norwegian Meteorological Institute database (http://eklima.met. no/), and we used the data from Bodø (107 km east of Hernyken) and Vardø Radio (2 km south of Hornøya) as proxies of air temperatures at Hernyken and Hornøуа, respectively. Although there is a meteorological station at Røst, we did not use the data from there because they were incomplete. The Bodø data were chosen instead as they proved to be a very good proxy of the parallel data from Røst (Pearson's $\mathrm{r}^{2}=0.954$, $F_{1,310}=6390, \mathrm{p}=0.000$ ). The wNAO indices (stationbased, December through March) were downloaded from the Climate Analysis Section of the National Center for Atmospheric Research (www.cgd.ucar.edu/cas/ jhurrell/indices.html).

Age-specific abundance indices of 5 fish species known to be important prey for north-Norwegian Atlantic puffins (all age classes of capelin, except 0-group; and 0- and 1-group herring, haddock Melanogrammus aeglefinus, saithe Pollachius virens and cod; Barrett 2002, Anker-Nilssen \& Aarvak 2006) were extracted with permission from ICES $(2010 a, b)$. 
The 2 study colonies are $900 \mathrm{~km}$ apart (shortest seaway) and in different marine ecoregions (Hernyken in the Norwegian Sea, Hornøya in the Barents Sea). Furthermore, their positions differ greatly in relation to the known spawning grounds of capelin (mainly in the Barents Sea) and the spawning grounds (mainly in the Norwegian Sea; Gjøsæeter et al. 2009b) and northeasterly drift of larval NSS herring and gadoid species in late winter/early-mid spring (e.g. Sætre et al. 2002). Within their first year, most of the surviving herring and cod drift along the coast of Norway into the Barents Sea, whereas the young saithe settle in the kelp forest, where they spend most of their immaturity. The 1-group fish of these 3 species are thus outside the pelagic foraging range of Atlantic puffins breeding in the Røst area in spring. Around Hornøya, however, the 0-group fish of the same species arrive too late to be of importance for local seabirds before egg-laying in early May. For herring, saithe and cod, we therefore limited our analyses to include only 0-group abundance (Herr0, Saithe0, Cod0) for Hernyken, and only 1-group abundance (Herr1, Saithe1, Cod1) for Hornøya. Capelin was omitted from the analysis for Hernyken because this prey does not occur within the normal foraging range for seabirds breeding at Røst. For haddock we only included 1-group (Hadd1) in the analyses because the main spawning period (April) occurs too late for the 0-group to be an adequate prey of puffins in early May. Except for sandeels (for which there are no abundance data in the Norwegian and Barents Seas) and capelin, 2-group and older fish of the other species are too big to be an important component of Atlantic puffin diet (their gadoid and clupeid prey are rarely $>10 \mathrm{~cm}$ long; e.g. AnkerNilssen \& Aarvak 2006, Harris \& Wanless 2011) and were thus excluded from the analyses.

Using the same reasoning, and because year class strengths of these prey species are mainly determined by environmental conditions in their first year of life (e.g. Toresen \& Østvedt 2000, Sætre et al. 2002), we only included the wNAO index for the previous winter in models for Hernyken and for the winter prior to that (i.e. 1 yr earlier) $\left(\mathrm{wNAO}_{\operatorname{lag} 1}\right)$ in models for Hornøya.

\section{Data analysis}

For body mass, we first excluded data from the pre-breeding and egg-laying periods in April-May because there was usually no such sampling at Hernyken in those periods between 1983 and 1996 and the birds tend to be much heavier in spring than later in the season (Barrett et al. 1985).
Initially, we used generalised linear models (GLMs) to examine the change in egg volume, size of adult birds and breeding phenology (i.e. timing of egglaying) at the 2 colonies through time, assuming a Gaussian error structure (Crawley 2007). We compared different candidate models, with main effects of colony, time and their 2-way interaction to examine to what extent the 2 colonies displayed different temporal patterns and/or general differences in response variables.

Next, we used multiple regression models to examine the effects of biologically relevant covariates (see previous subsection) on egg volume through time in the 2 colonies. However, because the observed time trend (see 'Results') in egg volume complicated the analysis, we first assessed to what extent we could model a linear trend together with main effects of all the environmental covariates. In both colonies, time had a high variance inflation factor (VIF; Zuur et al. 2009) of 4.57 at Hernyken and 5.52 at Hornøya such that we could not model a linear time effect directly together with the main effects of the environmental covariates. We thus opted to model the direct effect of the environmental covariates on the observed egg volume. To accommodate the potential time trend in the residuals (i.e. non-independence due to a temporal trend), we used generalised least-square (GLS) models (see Zuur et al. 2009) implemented by the gls function in the R add-on package nlme (Pinheiro et al. 2011), in which we applied a first-order auto-regression (AR1) auto-correlation structure to account for this non-independence. Models were compared based on their corrected Akaike (AICc) values, and AICc weights $\left(\mathrm{w}_{\mathrm{i}}\right)$ were calculated following Burnham \& Anderson (2002).

Simple descriptive statistics and bivariate tests were conducted using IBM SPSS Statistics (version 19.0), whereas multivariate models were run in the free statistical software R 2.12.1 (R Development Core Team 2010). For any parameter, annual sample sizes $<7$ were omitted. When we had repeated measurements of an adult within a season, we used the mean value in the analyses.

\section{RESULTS}

\section{Size of eggs}

The mean $( \pm \mathrm{SE})$ volume of Atlantic puffin eggs at Hornøya and Hernyken decreased significantly by $83 \pm 17$ and $48 \pm 16 \mu \mathrm{yr}^{-1}$, respectively, over the 30 yr study period (Table 1, Fig. 1; Table S1 in the 
Table 1. Fratercula arctica. Linear regression analysis of mean size measurements ( $\pm 1 \mathrm{SE})$ of eggs and adults at the 2 study sites and Isle of May, SE Scotland (see 'Discussion') against year (1973-2011). Raw data in Table S1 in the supplement

\begin{tabular}{|c|c|c|c|c|c|}
\hline $\begin{array}{l}\text { Parameter } \\
\text { Colony }\end{array}$ & Slope & $\mathrm{r}$ & $F$ & df & $\mathrm{p}$ \\
\hline \multicolumn{6}{|c|}{ Egg volume } \\
\hline Hornøya & $-0.083 \pm 0.017$ & 0.704 & 24.52 & 1,25 & $<0.001$ \\
\hline Hernyken & $-0.048 \pm 0.016$ & 0.532 & 8.671 & 1,22 & 0.007 \\
\hline Isle of May & $-0.051 \pm 0.043$ & 0.509 & 1.402 & 1,4 & 0.302 \\
\hline \multicolumn{6}{|c|}{ Wing length } \\
\hline Hornøya & $0.082 \pm 0.029$ & 0.725 & 7.766 & 1,7 & 0.027 \\
\hline Hernyken & $-0.003 \pm 0.016$ & 0.038 & 0.036 & 1,25 & 0.852 \\
\hline \multicolumn{6}{|c|}{ Head+bill length } \\
\hline Hornøya & $0.002 \pm 0.014$ & 0.007 & 0.013 & 1,6 & 0.912 \\
\hline Hernyken & $0.036 \pm 0.010$ & 0.663 & 14.12 & 1,18 & 0.001 \\
\hline
\end{tabular}

supplement), but there was no significant difference in slope between the 2 colonies $\left(F_{1,47}=2.140, \mathrm{p}=\right.$ $0.150)$. In the $23 \mathrm{yr}$ when both sites were sampled (1989-2011), there was also a significant correlation in egg volume between the 2 sites (Pearson's $\mathrm{r}=$ $0.433, \mathrm{p}=0.039$ ), with the overall mean size of eggs laid on Hornøya ( $65.4 \mathrm{ml}, \mathrm{SE}=0.22)$ being on average $6.3 \%$ larger than on Hernyken $(61.5 \mathrm{ml}, \mathrm{SE}=$ 0.11 ). Although there were large changes in egg volume between consecutive years, ranging from $-2.2 \%$ to $+3.2 \%$ of mean egg size (Fig. 1), these changes were not synchronous at the 2 Norwegian colonies (Pearson's $\mathrm{r}=0.237, \mathrm{p}=0.288, \mathrm{n}=22$ ).

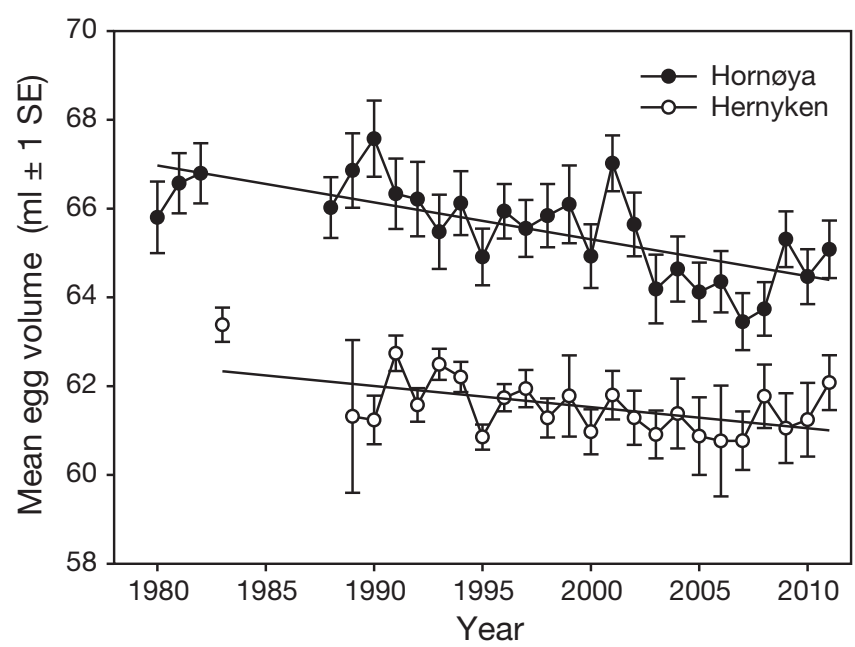

Fig. 1. Fratercula arctica. Trends in mean egg size (estimated volume $\pm 1 \mathrm{SE}$ ) at 2 North Norwegian colonies over the 32 yr period 1980-2011. See Table S1 in the supplement for annual data and Table 1 for test results

\section{Size of adults}

In contrast to the decrease in egg size, there were only very small changes in some size parameters of adult birds sampled at the 2 colonies during the study period (Table 1; Table $\mathrm{S} 1$ in the supplement). At Hornøya, wing length tended to increase while head+bill was stable, whereas wing length was stable and head+bill increased at Hernyken. At Hernyken, there was also a clear increase in the number of bill grooves (corresponding to $5.3 \%$ or 0.18 grooves in $30 \mathrm{yr}$ ) and a non-significant $(\mathrm{p}=$ $0.057)$ increase in bill depth at gonys ( $1.5 \%$ in $30 \mathrm{yr})$ (Table 2; Table S2 in the supplement at www.int-res. com/articles/suppl/m457p001_supp.pdf).

\section{Breeding phenology}

When excluding one extreme year (1996) at Hernyken when only some of the latest-laid eggs were incubated long enough to hatch (and allowed calculation of their laying date), the variation in mean annual egg-laying dates ranged over $17.6 \mathrm{~d}$ at Hornøya and $20.1 \mathrm{~d}$ at Hernyken. No long-term trends were evident at either colony (Table 3, Fig. 2; Table S3 in the supplement at www.int-res.com/articles/suppl/ m457p001_supp.pdf), nor were there any apparent relationships between egg volume and laying date (Pearson's correlations: Hornøya: $\mathrm{r}=-0.259, \mathrm{p}=0.193$, $\mathrm{n}=27$; Hernyken: $\mathrm{r}=-0.077, \mathrm{p}=0.740, \mathrm{n}=21$ ).

Table 2. Fratercula arctica. Linear regression analysis of mean size measurements $( \pm 1 \mathrm{SE})$ of adults taken during the breeding season on Hernyken against year (1980-2009). Raw data in Table S2 in the supplement

\begin{tabular}{|cccccc|}
\hline Parameter & Slope & $\mathrm{r}$ & $F$ & $\mathrm{df}$ & $\mathrm{p}$ \\
\hline $\begin{array}{c}\text { Culmen } \\
\text { length }\end{array}$ & $-0.006 \pm 0.012$ & 0.110 & 0.232 & 1,19 & 0.636 \\
$\begin{array}{c}\text { Bill depth } \\
\begin{array}{c}\text { No. of bill } \\
\text { grooves } \\
\text { Body mass }\end{array}\end{array}$ & $0.018 \pm 0.009$ & 0.432 & 4.118 & 1,18 & 0.057 \\
\hline
\end{tabular}

Table 3. Fratercula arctica. Linear regression analysis of mean laying date (mean May date $\pm 1 \mathrm{SE}$ ) on Hornøya and Hernyken against year (1978-2011). Raw data in Table S3 in the supplement

\begin{tabular}{|lrcccc|}
\hline Colony & Slope & $\mathrm{r}$ & $F$ & $\mathrm{df}$ & $\mathrm{p}$ \\
\hline Hornøya & $-0.055 \pm 0.090$ & 0.123 & 0.382 & 1,25 & 0.542 \\
Hernyken & $0.139 \pm 0.138$ & 0.186 & 1.008 & 1,28 & 0.324 \\
\hline
\end{tabular}




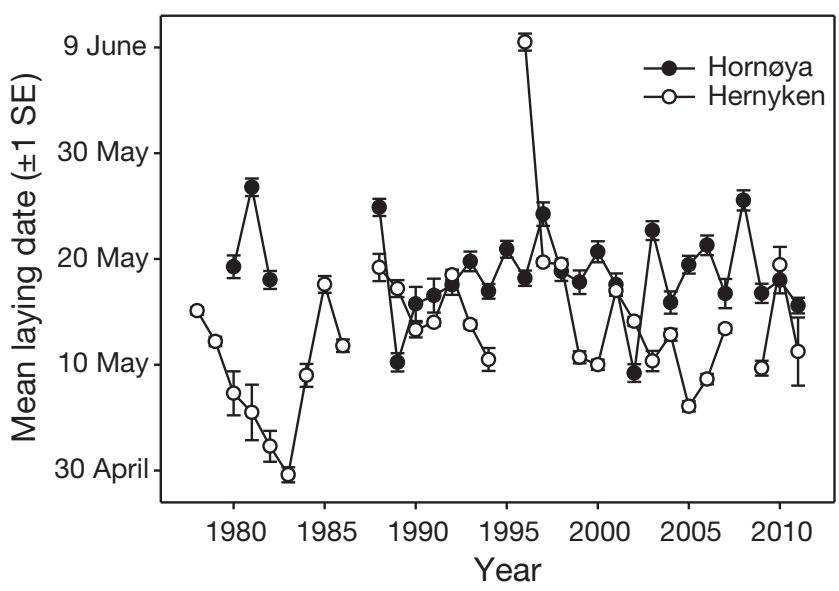

Fig. 2. Fratercula arctica. Inter-annual variation in laying date at 2 North Norwegian study sites over the $34 \mathrm{yr}$ period 1978-2011. See Table S3 in the supplement for annual data and Table 3 for test results

\section{Relationship between egg volume and environmental covariates}

When modelling direct effects of the covariates on egg volume, model selection based on AICc suggested that contrasting patterns were operating at the 2 colonies (Table 4). Egg volume at Hornøya was best modelled with a GLS function including the effects of wNAO $\mathrm{wag}_{1}$, Herr1, capelin and Hadd1. Parameter estimates (after standardisation of covariates) suggested a positive effect of $\mathrm{wNAO}_{\text {lag1 }}(\beta=0.31 \pm$ $0.11 \mathrm{SE})$ and capelin abundance $(\beta=0.64 \pm 0.09 \mathrm{SE})$, and a negative effect of Herr1 $(\beta=-0.32 \pm 0.09 \mathrm{SE})$ and Hadd1 $(\beta=-0.70 \pm 0.08 \mathrm{SE})$. Compared to the second best model in the set of candidate models, this model was 6.9 times more likely to be the best model in the set. At Hernyken, the selected model based on the AICc values included the main effect of SST in April $\left(\mathrm{SST}_{\text {April }}\right)$ only, with a standardised effect size estimated at $\beta=-0.31$ ( $\mathrm{SE}=0.10)$. Compared to the second-rank model in the set, this model was, however, only 1.60 times more likely to be the best. The second-ranked model included, in addition to the negative effect of $\mathrm{SST}_{\text {April, }}$ a positive effect of Herr0 with a standardised effect size estimated at $\beta=0.18$ $(\mathrm{SE}=0.10)$.

\section{DISCUSSION}

\section{Intrinsic factors}

We found a significant decline in Atlantic puffin egg volume at 2 widely separated Norwegian colonies situated in different marine ecoregions, a decline that is unprecedented among auks. The 2 study populations were, however, characterised by highly different trends in breeding numbers over the sampling period, and without knowing the sex and age distribution of the population and experience of the parents or having annual measurements of recruitment rates, we cannot easily control for any changes in the demographic structure of the samples. The parallel trends in egg size strongly suggest, however, that such intrinsic effects were not masking the influence of other, more important factors.

Table 4. Fratercula arctica. Model results used to evaluate direct effects of environmental covariates on egg volume at Hornøya and Hernyken during the years 1989-2007 for which data exists for all variables. Generalised least-square (GLS) models were fitted to the data with a first-order auto-regression (AR1) auto-correlation structure in the residuals. Description of models follows R-notation. See 'Materials and methods: Environmental covariates and data selection' for description of the covariates. AICc: corrected Akaike values, $w_{i}$ : AICc weights. For each colony, the best model is indicated in bold

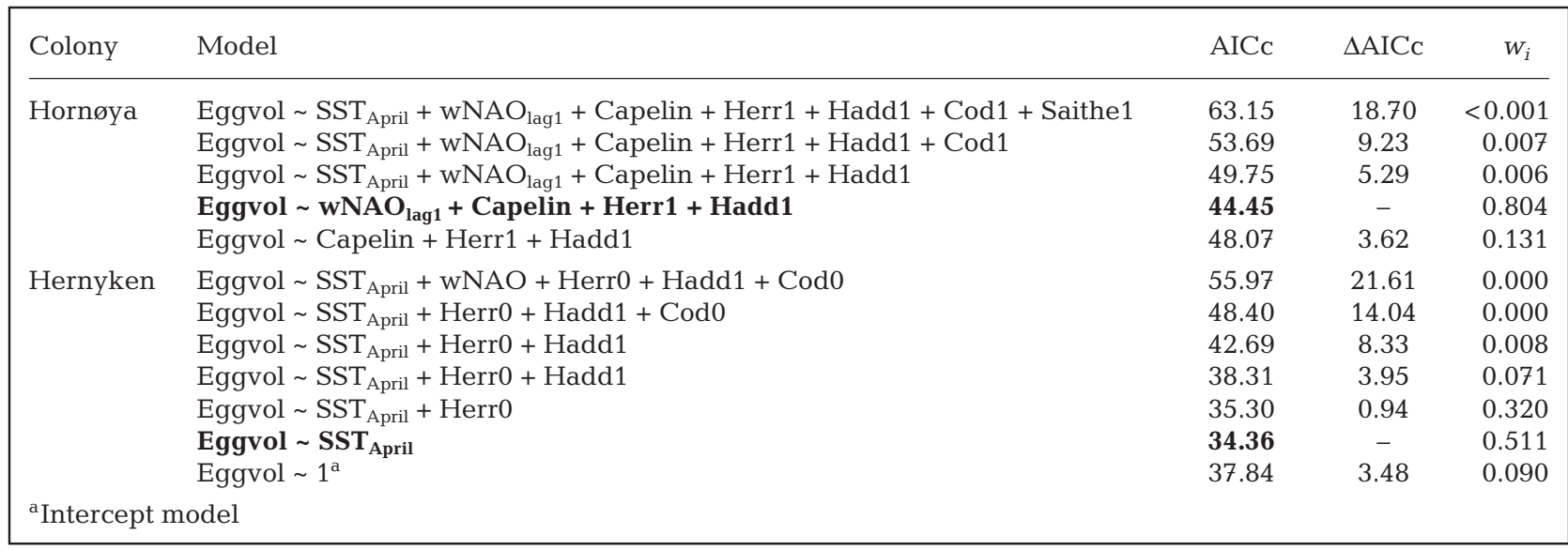


Whereas Barrett (2001) found no decline in Atlantic puffin egg size on Hornøya between 1980 and 2000, the inclusion of a further $11 \mathrm{yr}$ of data plus the data from Hernyken clearly shows that one or more factors are affecting puffin egg size in north Norway. A similar, although insignificant trend is also evident in data from the Isle of May, SE Scotland, where Atlantic puffin eggs tended to decrease in volume between 1973 and 2009 (Table 1; Table S1 in the supplement; M. P. Harris pers. comm.). This may suggest that the change in egg size occurred at a wider geographical scale, including at least 3 different marine ecoregions in the NE Atlantic: the Barents, Norwegian and North Seas.

Egg size is influenced by fitness trade-offs during egg-laying and by maternal characteristics such as age, breeding experience and body size (larger eggs are laid by larger and sometimes older, more experienced birds) and the timing of laying (late breeders lay smaller eggs) and also by environmental factors such as food availability or ambient temperature (Christians 2002). Among many species of both single- and multi-egg layers, egg and/or clutch sizes decrease with laying date (Hipfner et al. 1997 and references therein). Laying smaller eggs late in the season may be adaptive in that it saves time and energy, and thus accommodates adverse late-season conditions (Hipfner et al. 2005), although Hipfner et al. (1997) showed that for Brünnich's guillemots Uria lomvia this held true only for young ( $\leq 8 \mathrm{yr}$ ) birds, thus weakening the adaptive hypothesis. On Hornøya and Hernyken, there was, however, no evidence of a long-term change in laying dates (Fig. 2) or of any relationship between egg volume and laying date at either colony, thus ruling out effects of breeding phenology on egg volume.

In another study of a single-egg layer, the northern fulmar Fulmarus glacialis, Michel et al. (2003) showed that of the female traits, body size explained most variation in egg size. It is thus plausible that a change in body size was the cause of the decline in egg size in that study. Using various measurements as proxies of body size, there was, however, no evidence of a contemporary and parallel change in adult puffin body size that could explain the decrease in egg volume of Atlantic puffins on Hornøya and Hernyken (Table 1). For example, at Hernyken, there was no correlation between egg size and any of the 6 body measurements of adult birds (all $\mathrm{p} \geq 0.141$ ). Wing and head+bill lengths are among those most consistently measured by different observers (Barrett et al. 1989), and the present study results indicate that body size was stable or even increasing at both sites.
As experienced birds lay larger eggs than young, inexperienced individuals (e.g. Sæther 1990), another possible explanation for the decrease in volume over the years is a change in age-structure of the populations of breeding adults towards younger birds. However, at Hernyken, the mean age of breeders most likely increased over the study period as a result of the very poor reproduction in the colony throughout the study period (e.g. Durant et al. 2003, 2006, Harris et al. 2005). This assumption was corroborated by an observed increase in the number of bill grooves and a tendency towards a larger depth of the adults' bills (Table 2), the most distinctive sexual ornament in this species (Harris \& Wanless 2011). Such ageing in the population might predict a longterm increase or stability in egg size, at least until outweighed by effects of senescence (e.g. Reid 1988), yet in the present study, eggs decreased in size. Similarly, assuming no change in immigration rates from other colonies, any change in age structure towards younger birds is unlikely on Hornøya, as there is no evidence of a consistent change in breeding success prior to 2007 (2007-2011 omitted to allow 5 yr for recruitment; ANOVA on regression: $\mathrm{r}=0.072, F_{1,14}=$ 0.073, p = 0.791). As such, an increase in recruitment of inexperienced birds into the population over the years that would cause such a change in age structure is unlikely. On Hernyken, on the other hand, breeding success in 1975-2006 did increase significantly (ANOVA on regression: $\mathrm{r}=0.390, F_{1,30}=5.383$, $\mathrm{p}=0.027$ ). The mean egg volume did not, however, correlate with body size, nor did egg volume correlate with mean breeding success 4 to 6 yr earlier at either colony (cross-correlations against individual years and the $3 \mathrm{yr}$ running average, all $\mathrm{p} \geq 0.138$ ), suggesting again that the decrease in egg size was not caused by a major demographic change.

\section{Environmental factors}

Martin (2008) suggested that large eggs may partly compensate for the increased energetic requirements of a cold environment and long incubation periods among inattentive parents (such as Atlantic puffins; Harris \& Wanless 2011) and showed that relative (to body size) egg size decreases with increasing average egg temperatures. There was, however, no significant change in mean pre-laying (April) air temperature on Hornøya (ANOVA on regression: $\mathrm{r}=$ $\left.0.349, F_{1,30}=4.15, \mathrm{p}=0.050\right)$ or Hernyken $(\mathrm{r}=0.332$, $\left.F_{1,30}=3.73, \mathrm{p}=0.063\right)$ during the study period (1980-2011), and our exploratory modelling showed 
that air temperatures did not help explain the interannual variation in egg size.

Studies of black-legged kittiwakes Rissa tridactyla and common guillemots Uria aalge have shown that egg size reflects current food limitations ('constraint hypothesis', e.g. Bolton et al. 1993, Gill \& Hatch 2002) rather than anticipated food during the chick-rearing period ('anticipation hypothesis', e.g. Shultz et al. 2009). Thus, the decline in egg size of Atlantic puffins may be due to rising sea temperatures or other oceanographic changes imposing energetic constraints on the female through a mismatch between food availability early in the season and egg formation (e.g. Watanuki et al. 2009). If within-season timing of events was the key element, one might expect that such a mismatch would lead to changes in the timing of breeding. We found, however, no evident trends in the timing of breeding (as indicated by laying date). Nor was there any relationship between SST in April and laying date at either colony (ANOVA on regression: Hornøya: $\mathrm{r}=0.110, F_{1,25}=$ $0.307, \mathrm{p}=0.584$; Hernyken, excluding 1996: $\mathrm{r}=0.258$, $\left.F_{1,27}=1.924, \mathrm{p}=0.177\right)$. This suggests that the change in egg volume was driven by inter-annual changes in pre-breeding prey abundance, as supported by the results of our multivariate modelling where we included a regional climate signal (wNAO) and a local indicator of oceanographic conditions ( $\mathrm{SST}_{\mathrm{April}}$ ) that could reflect general variations in pre-laying food availability for the puffins, in addition to abundance data for some of the puffins' main fish prey.

The positive effect of capelin and negative effect of herring on egg size at Hornøya indicate that the trend is linked to the ecosystem shift associated with the recovery of the NSS herring stocks in Norwegian waters, with an increase in strong year classes of immature herring depleting the capelin in the Barents Sea (e.g. Hjermann et al. 2004). The positive effect of wNAO in the previous year suggests, however, that there are also other factors in this equation, probably related to availability of other prey that might be more important early in the season. At Røst, sea temperature alone produced the best model, although the inclusion of 0 -group herring did not seriously reduce the fit. Thus, even if herring is important, this strongly suggests that other prey played a larger role in determining the puffin egg size. Recent stable-isotope studies (Davies et al. 2009, Hedd et al. 2010) have suggested that Atlantic puffins and their sibling species tufted puffins Fratercula cirrhata prey on zooplankton in winter and the early breeding season. Furthermore, Sorensen et al. (2009) showed that pre-breeding female Cassin's auklets Ptychoramphus aleuticus that fed on energetically superior copepods laid earlier and larger eggs than those that fed on poorer juvenile rockfish Sebastes spp. Thus, climatic effects may be mediated through their effect on lower trophic levels and, because tendencies towards a decrease in the amount of zooplankton and changes in its species composition in the Norwegian and Barents Seas have been in evidence since 1995 (Agnalt et al. 2011), possible links between climate, zooplankton, prey fish and puffin egg size should be further explored.

It may be argued that an increase in SST may actually promote an increase in egg size through a relaxation of thermoregulatory costs. The metabolic cost of producing an egg is high (ca. $50 \%$ of standard metabolic rate during the period of yolk deposition, 10 to $15 d_{i}$ Astheimer \& Grau 1990) such that rising SSTs may reduce thermoregulation costs for the female and thus enhance the possibility to channel more energy into larger eggs (Stevenson \& Bryant 2000). In our study, however, egg volume was negatively correlated with SST, indicating that thermoregulatory costs were insignificant compared to changes in abundances of the puffins' main prey.

\section{Possible population-level effects of chick fitness}

Any correlation between the fitness of offspring and egg size is confounded by correlations between egg size and the quality of the female and hence her (and the male's) ability to raise chicks. Nevertheless, there is evidence that under poor feeding conditions, chick growth is correlated with egg size, although in multi-egg clutches this is confounded by a trade-off between clutch size and heavier eggs (Styrsky et al. 1999). A cross-fostering study by Hipfner et al. (2001) of Brünnich's guillemots that lay single-egg clutches found that chicks from large eggs initiated linear wing growth sooner after hatching and also tended to remain larger than chicks from small eggs. However, they also found that at another colony, this tendency only occurred in a year when chicks grew slowly, again offering support for the hypothesis that large eggs confer greater advantage when feeding conditions are poor. Although studies of long-term effects are lacking, it has been shown that egg size influences offspring fitness, including survival and, thus, also offspring reproductive success (Gaston 1997, Krist 2011, Lee et al. 2012). We therefore cannot rule out that the long-term decrease in egg size of Atlantic puffins demonstrated in our study will affect, or possibly already has affected, the quality of new 
breeders to the populations in question, especially in colonies where years of poor breeding success have been frequent, such as in Røst.

Acknowledgements. We thank the numerous people who assisted in collecting field data at the study colonies, and M. P. Harris (Centre for Ecology and Hydrology, Scotland) for information from the Isle of May. ICES kindly permitted us to use fish stock estimates provided by the AFWG and WGWIDE working groups. Thanks are also due to E. Solberg for statistical advice and M. P. Harris and 4 anonymous referees for valuable comments on the manuscript. The long-term field work at the Norwegian colonies was part of a number of different projects, including the National seabird monitoring programme at the Norwegian Institute for Nature Research (NINA) and the Population ecology of Atlantic puffins in Røst, and supported financially by the Directorate for Nature Management, the Norwegian Research Council, Statoil, Norsk Hydro, Amoco, BP Norway, the Norwegian Oil Industry Association and, from 2005, the SEAPOP programme (www.seapop.no), as well as our affiliated institutions NINA and Tromsø University Museum.

\section{LITERATURE CITED}

Agnalt AL, Fossum P, Hauge M, Magnor-Jensen A and others (eds) (2011) Havforskningsrapporten 2011. Fisken og havet, særnr. 1-2011. Institute of Marine Research, Bergen

Anker-Nilssen T (2010) Key-site monitoring in Røst in 2009. SEAPOP Short Report 12-2010. www.seapop.no/opencms/ export/sites/SEAPOP/no/files/short-reports/2010/2010_ 12_SEAPOP_Short_Report.pdf

Anker-Nilssen T (2011) Mainland Norway. In: Harris MP, Wanless S (eds) The puffin. Poyser, Calton, p 62-64

Anker-Nilssen T, Aarvak T (2006) Long-term studies of seabirds in the municipality of Røst, Nordland. Results with focus on 2004 and 2005. NINA Report no. 133. Norwegian Institute for Nature Research, Trondheim (in Norwegian with English summary and subtitles)

Astheimer LB, Grau CR (1990) A comparison of yolk growth rates in seabird eggs. Ibis 132:380-394

Barrett RT (2001) The breeding demography and egg size of north Norwegian Atlantic puffins Fratercula arctica and razorbills Alca torda during 20 years of climatic variability. Atl Seabirds 3:97-112

Barrett RT (2002) Atlantic puffin Fratercula arctica and common guillemot Uria aalge chick diet and growth as indicators of fish stocks in the Barents Sea. Mar Ecol Prog Ser 230:275-287

- Barrett RT, Fieler R, Anker-Nilssen T, Rikardsen F (1985) Measurements and weight changes of Norwegian adult puffins Fratercula arctica and kittiwakes Rissa tridactyla during the breeding season. Ringing Migr 6:102-112

Barrett RT, Peterz M, Furness RW, Durinck J (1989) The variability of biometric measurements. Ringing Migr 10: 13-16

Barrett RT, Lorentsen SH, Anker-Nilssen T (2006) The status of breeding seabirds in mainland Norway. Atl Seabirds 8:97-126

> Blight LK (2011) Egg production in a coastal seabird, the glaucous-winged gull (Larus glaucescens), declines dur- ing the last century. PLoS ONE 6:e22027

Bolton M, Monaghan P, Houston DC (1993) Proximate determination of clutch size in lesser black-backed gulls: the roles of food supply and body condition. Can J Zool 71:273-279

Burnham KP, Anderson DR (2002) Model selection and multimodel inference: a practical information-theoretic approach. Springer-Verlag, New York, NY

Burrows MT, Schoeman DS, Buckley LB, Moore P and others (2011) The pace of shifting climate in marine and terrestrial ecosystems. Science 334:652-655

> Christians JK (2002) Avian egg size: variation within species and inflexibility within individuals. Biol Rev Camb Philos Soc 77:1-26

Crawley MJ (2007) The R book. Wiley, Chichester

> Cury PM, Boyd IL, Bonhommeau S, Anker-Nilssen T and others (2011) Global seabird response to forage fish depletion - one-third for the birds. Science 334:1703-1706

> Davies WE, Hipfner JM, Hobson KA, Ydenberg RC (2009) Seabird seasonal trophodynamics: isotopic patterns in a community of Pacific alcids. Mar Ecol Prog Ser 382: 211-219

Drent R, Daan S (1980) The prudent parent: energetic adjustments in avian breeding. Ardea 68:225-252

> Durant JM, Anker-Nilssen T, Stenseth NC (2003) Trophic interactions under climate fluctuations: the Atlantic puffin as an example. Proc R Soc Lond B 270:1461-1466

> Durant JM, Anker-Nilssen T, Stenseth NC (2006) Ocean climate prior to breeding affects the duration of the nestling period in the Atlantic puffin. Biol Lett 2:628-631

Fauchald P, Skov H, Skern-Mauritzen M, Johns D, Tveraa T (2011) Wasp-waste interactions in the North Sea ecosystem. PLoS ONE 6:e22729

Gaston AJ (1997) Mass and date at departure affect the survival of ancient murrelet Synthliboramphus antiquus chicks after leaving the colony. Ibis 139:673-678

Gill VA, Hatch SA (2002) Components of productivity in black-legged kittiwakes Rissa tridcactyla: response to supplemental feeding. J Avian Biol 33:113-126

Gjøsæter H, Bogstad B, Tjelmeland S (2009a) Ecosystem effects of the three capelin stock collapses in the Barents Sea. Mar Biol Res 5:40-53

Gjøsæter H, Dommasnes A, Falkenhaug T, Hauge M, Johannesen E, Olsen E, Skagseth Ø (eds) (2009b) Havets ressurser og miljø 2009. Fisken og havet, særnr. 1-2009. Institute of Marine Research, Bergen

Halpern BS, Walbridge S, Selkoe KA, Kappel CV and others (2008) A global map of human impact on marine ecosystems. Science 319:948-952

Harris MP, Wanless S (2011) The puffin. Poyser, Calton

> Harris MP, Anker-Nilssen T, McCleery RH, Erikstad KE, Shaw DN, Grosbois V (2005) Effect of wintering area and climate on the survival of adult Atlantic puffins Fratercula arctica in the eastern Atlantic. Mar Ecol Prog Ser 297:283-296

> Hedd A, Fifield DA, Burke CM, Montevecchi WA and others (2010) Seasonal shift in the foraging niche of Atlantic puffins Fratercula arctica revealed by stable isotope $\left(\delta^{15} \mathrm{~N}\right.$ and $\left.\delta^{13} \mathrm{C}\right)$ analyses. Aquat Biol 9:13-22

> Hipfner JM, Gaston AJ, de Forest LN (1997) The role of female age in determining egg size and laying date of thick-billed murres. J Avian Biol 28:271-278

> Hipfner JM, Gaston AJ, Storey AE (2001) Food supply and the consequences of egg size in the thick-billed murre. Condor 103:240-247 
Hipfner JM, Gaston AJ, Gilchrist HG (2005) Variation in egg size and laying date in thick-billed murre populations breeding in the Low Arctic and High Arctic. Condor 107:657-664

Hjermann DØ, Stenseth NC, Ottersen G (2004) Indirect climatic forcing of the Barents Sea capelin: a cohort effect. Mar Ecol Prog Ser 273:229-238

Hoyt DF (1979) Practical method of estimating volume and fresh weight of bird eggs. Auk 96:73-77

ICES (2010a) Report of the Arctic Fisheries Working Group (AFWG). ICES CM 2010/ACOM:05. ICES, Copenhagen

ICES (2010b) Report of the Working Group on Widely Distributed Stocks (WGWIDE). ICES CM 2010/ACOM:15. ICES, Copenhagen

$>$ Jacobs SR, Elliott KH, Gaston AJ, Weber JM (2009) Fatty acid signatures of female Brünnich's guillemots Uria lomvia suggests reliance on local prey for replacement egg production. J Avian Biol 40:327-336

Kålås JA, Viken Å, Henriksen S, Skjelseth S (eds) (2010) The 2010 Norwegian Red List for species. Norwegian Biodiversity Information Centre, Norway

Krist M (2011) Egg size and offspring quality: a metaanalysis in birds. Biol Rev Camb Philos Soc 86:692-716

Lee DE, Warzybok PM, Bradley RW (2012) Recruitment of Cassin's auklet (Ptychoramphus aleuticus): individual age and parental age effects. Auk 129:124-132

Martin TE (2008) Egg size variation among tropical and temperate song birds: an embryonic temperature hypothesis. Proc Natl Acad Sci USA 105:9268-9271

Michel P, Ollason JC, Grosbois V, Thompson PM (2003) The influence of body size, breeding experience and environmental variability on egg size in the northern fulmar (Fulmarus glacialis). J Zool (Lond) 261:427-432

Myrberget S (1962) Undersøkelser over forplantningsbiologien til lunde (Fratercula arctica (L.)) egg, ruging og unger. Medd St Viltunders 2:1-51 (in Norwegian with English Abstract)

Nager RG (2006) The challenges of making eggs. Ardea 94:323-346

Piatt JF, Harding AMA, Shultz M, Speckman SG, van Pelt TI, Drew GS, Kettle AB (2007) Seabirds as indicators of marine food supplies: Cairns revisited. Mar Ecol Prog Ser 352:221-234

Pinheiro J, Bates D, DebRoy S, Sarkar D, R Development Core Team (2011) nlme: linear and nonlinear mixed effects models. R package version 3.1-98. R Foundation for Statistical Computing, Vienna

Potti J (2008) Temperature during egg formation and the

Editorial responsibility: John Piatt,

Anchorage, Alaska, USA effect of climate warning on egg size in a small songbird. Acta Oecol 33:387-393

R Development Core Team (2010) R: a language and environment for statistical computing. R Foundation for Statistical Computing, Vienna

Ratcliffe N (2004) Causes of seabird population change. In: Mitchell PI, Newton SF, Ratcliffe N, Dunn TE (eds) Seabird populations of Britain and Ireland. Results of the seabird 2000 census (1998-2002). Poyser, London, p 407-437

Reid WV (1988) Age-specific patterns of reproduction in the glaucous-winged gull: increased effort with age. Ecology 69:1454-1465

Sæther BE (1990) Age specific variation in reproductive performance in birds. Curr Ornithol 7:251-283

Sætre R, Toresen R, Søiland H, Fossum P (2002) The Norwegian spring-spawning herring - spawning, larval drift and larval retention. Sarsia 87:167-178

Shultz MT, Piatt JF, Harding AMA, Kettle AB, van Pelt TI (2009) Timing of breeding and reproductive performance in murres and kittiwakes reflect mismatched seasonal prey dynamics. Mar Ecol Prog Ser 393:247-258

Skjoldal HR (ed) (2004) The Norwegian Sea ecosystem. Tapir Academic Press, Trondheim

Sorensen MC, Hipfner JM, Kyser TK, Norris DR (2009) Carry-over effects in a Pacific seabird: stable isotope evidence that pre-breeding diet quality influences reproductive success. J Anim Ecol 78:460-467

Stearns SC (1992) The evolution of life histories. Oxford University Press, Oxford

Stevenson IR, Bryant DM (2000) Climate change and constraints on breeding. Nature 406:366-367

> Styrsky JD, Eckerle KP, Thompson CF (1999) Fitness-related consequences of egg mass in nestling house wrens. Proc R Soc Lond B 266:1253-1258

Toresen R, Østvedt OJ (2000) Variation in abundance of Norwegian spring-spawning herring (Clupea harengus, Clupeidae) throughout the 20th century and the influence of climatic fluctuations. Fish Fish 1:231-256

Watanuki Y, Ito M, Deguchi T, Minobe S (2009) Climateforced seasonal mismatch between the hatching of rhinoceros auklets and the availability of anchovy. Mar Ecol Prog Ser 393:259-271

Williams TD (2005) Mechanisms underlying the costs of egg production. Bioscience 55:39-48

Zuur AF, Ieno EN, Walker NJ, Saveliev AA, Smith GM (2009) Mixed effects models and extensions in ecology with R. Springer, New York, NY

Submitted: December 28, 2011; Accepted: May 12, 2012

Proofs received from author(s): June 5, 2012 